Research Paper

\title{
Ethanol production from agricultural wastes using Sacchromyces cervisae
}

\author{
Muhammad Irfan*, Muhammad Nadeem, Quratualain Syed \\ Food \& Biotechnology Research Center, Pakistan Council of Scientific and Industrial Reasearch \\ Laboratories Complex, Ferozpure Road Lahore, Pakistan.
}

Submitted: March 11, 2013; Approved: September 9, 2013.

\begin{abstract}
The main objective of this study was production of ethanol from three lignocellulosic biomasses like sugarcane bagasse, rice straw and wheat straw by Sacchromyces cervisae. All the three substrates were ground to powder form $(2 \mathrm{~mm})$ and pretreated with $3 \% \mathrm{H}_{2} \mathrm{O}_{2}+2 \% \mathrm{NaOH}$ followed by steaming at $130{ }^{\circ} \mathrm{C}$ for $60 \mathrm{~min}$. These substrates were hydrolyzed by commercial cellulase enzyme. The whole fermentation process was carried out in $500 \mathrm{~mL}$ Erlenmeyer flask under anaerobic conditions in submerged fermentation at $30^{\circ} \mathrm{C}$ for three days of incubation period. FTIR analysis of the substrates indicated significant changes in the alteration of the structure occurred after pretreatment which leads to efficient saccharification. After pretreatment the substrates were hydrolyzed by commercial cellulase enzyme and maximum hydrolysis was observed in sugarcane bagasse (64\%) followed by rice straw (40\%) and wheat straw (34\%). Among all these tested substrates, sugarcane bagasse $(77 \mathrm{~g} / \mathrm{L})$ produced more ethanol as compared to rice straw $(62 \mathrm{~g} / \mathrm{L})$ and wheat straw $(44 \mathrm{~g} / \mathrm{L})$ using medium composition of (\%) $0.25\left(\mathrm{NH}_{4}\right)_{2} \mathrm{SO}_{4}, 0.1 \mathrm{KH}_{2} \mathrm{PO}_{4}, 0.05 \mathrm{MgSO}_{4}, 0.25$ Yeast extract by $S$. cervisae.
\end{abstract}

Key words: lignoccellulosic biomass, Pretreatment, Sacchromyces cervisae, ethanol production.

\section{Introduction}

Lignocellulosic biomasses like wheat straw, sugarcane Bagasse and rice straw are the world renewable resource in the biosphere (Gruno et al., 2004). Among this rice straw is to be considered as the largest available biomass inn the world which is about $7.31 \times 10^{14}$ dry rice straw per year and Asia is the largest region in the world which is responsible for $90 \%$ of the annual global production (Kim and Dale, 2004). Sugarcane bagasse is the main by-product of sugarcane processing can also be used in fuel generation systems and produce more ethanol positively from corn. Lignocellulosic biomasses have only one problem is that enzymatic hydrolysis yield can not be greater than $20 \%$ of the theoretical maximum glucan conversion, even under a high level of enzyme loading or by employing longer reaction time (Kim and Lee, 2007). So to enhance this yield lignocellulosic biomasses need some pretreatment methods to alter the structure for greater enzyme accessibility for conversion of cellulose into glucose units. There are several pretreatment methods which can be employed on biomasses to alter their structure. Main pretreatment methods are; Milling and grinding, pyrolysis, high-energy radiation, high pressure steaming, alkaline or acid hydrolysis, gas treatment (chlorine dioxide, nitrogen dioxide, sulfur dioxide, ozone), hydrogen peroxide treatment, organic solvent treatment, hydrothermal treatment, steam explosion, wet oxidation and biological treatment (Mosier et al., 2005). The cellulose content present in these substrates is hydrolyzed by mixture of enzymes which converts it into glucose which is important factor in ethanol production from lignocellulosic biomasses (Curreli et al., 2002).

In Brazil and the United States, fuel ethanol is produced by fermentation of corn glucose in the US or sucrose in Brazil which are the largest ethanol producers in the world (MacDonald et al., 2001) but this can also be prepared from agro-residues according to the agronomicbased economy of the country. There are some potential methods for low cost ethanol production by using agricultural wastes (Krishna et al., 1999) and wheat straw is one of the most abundant agricultural wastes, has been extensively

Send correspondence to M. Irfan. Food \& Biotechnology Research Center, Pakistan Council of Scientific and Industrial Reasearch Laboratories Complex, 54600 Ferozpure Road Lahore, Pakistan. E-mail: mirfanashraf@yahoo.com, irfan.biotechnologist@gmail.com. 
studied (Ballesteros et al., 2004; Curreli et al., 1997). Ethanol can be produced by variety of microorganisms. Cellulose-to-ethanol bioconversion can be conducted by various anaerobic thermophilic bacteria, such as Clostridium thermocellum (Ingram et al., 1987), Zymomonas (Matthew et al., 2005), Engineered Escherichia coli (Millichip and Doelle, 1989) as well as by some filamentous fungi, including Monilia sp. (Saddler and Chan, 1982), Neurospora crassa (Gong et al., 1981), Neurospora sp. (Yamauchi et al., 1989), Zygosaccharomyces rouxii (Pastore et al., 1994), Aspergillus sp. (Sugawara et al., 1994), Trichoderma viride (Ito et al., 1990), and Paecilomyces sp. (Gervais and Sarrette, 1990). This study is focused on pretreatment of the lignocellulosic biomasses (sugarcane Bagasse, rice straw and wheat straw) and ethanol production from these biomasses using strain of Sacchromyces cervisiae in submerged fermentation.

\section{Materials and Methods}

\section{Lignocellulosic biomass}

Sugar cane bagasse procured from Shakar Gunj Sugar mills (Pvt.) Limited, Jhang Road, Faisalabad, Pakistan, and wheat straw and rice straw were purchased from a local market of Lahore city was used as a source of lignocellulosic biomass. The biomass was washed and dried to remove the unwanted particles and then milled into powder form $(2 \mathrm{~mm})$ with hammer beater mill.

\section{Microorganism}

Sacchromyces cervisae was obtained from microbiology laboratory, Food and Biotechnology Research Center (FBRC), PCSIR and maintained on PDA slants stored at $4{ }^{\circ} \mathrm{C}$ for further use.

\section{Pretreatment of biomasses}

Sugar cane bagasse and wheat straw samples were pretreated by method as reported earlier (Irfan et al., 2011a). The chopped sugar cane bagasse and wheat straw samples were soaked in $3 \% \mathrm{H}_{2} \mathrm{O}_{2}+2 \% \mathrm{NaOH}$ solution at the ratio of 1: 10 (solid : liquid) for $2 \mathrm{~h}$ at room temperature. After that samples were steamed at $130{ }^{\circ} \mathrm{C}$ for $60 \mathrm{~min}$. After steaming the samples were filtered and solid residues were washed up to neutrality.

\section{Determination of lignin}

The lignin content in treated and untreated samples was measured being considered as lignin the remaining solid residue after hydrolysis with $1.25 \% \mathrm{H}_{2} \mathrm{SO}_{4}$ for two hours and $72 \% \mathrm{H}_{2} \mathrm{SO}_{4}$ hydrolysis for four hours. The residue was filtered and washed with distilled water to remove sulphuric acid and oven dried at $105^{\circ} \mathrm{C}$ for constant weight. The lignin (\%) and delignification (\%) was expressed by using the following equations (Irfan et al., 2011a):

$$
\begin{aligned}
& \text { Lignin }(\%)=\frac{\text { Lignin weight }(\mathrm{g})}{\text { Substrate weight }(\mathrm{g})} \times 100 \\
& \text { Delignification }(\%)=\frac{\mathrm{L}_{\mathrm{u}}-\mathrm{L}_{\mathrm{t}}}{\mathrm{L}_{\mathrm{u}}} \times 100
\end{aligned}
$$

where $\mathrm{L}_{\mathrm{u}}=$ Lignin (untreated sample), and $\mathrm{L}_{\mathrm{t}}=$ Lignin (treated sample).

\section{Enzymatic hydrolysis}

Enzymatic hydrolysis was done as described earlier (Irfan et al., 2011a). Commercial enzyme with CMCase activity of $2900 \mathrm{IU} / \mathrm{mL}$ and filter paper activity of $1500 \mathrm{FPU} / \mathrm{mL}$ enzyme solution was used for the hydrolysis experiments. Pretreated substrates at 5\% solids loading (grams dry weight per $100 \mathrm{~mL}$ ) in distilled water were incubated in flasks in a shaking water bath at $50{ }^{\circ} \mathrm{C}$ and $140 \mathrm{rpm}$ for $8 \mathrm{~h}$. After termination of enzymatic hydrolysis the material was centrifuged at $10,000 \mathrm{rpm}$ for $10 \mathrm{~min}$. The supernatant was removed for sugar content analysis. Saccharification (\%) was calculated as described by Uma et al. (2010).

Saccharification $(\%)=$

$$
\frac{\text { Reducing sugars }(\mathrm{g}) \times 0.9}{\text { Cellulo content in pretreated substrate }} \times 100
$$

\section{Ethanol production}

The medium used for ethanol fermentation composed of (\%) $0.25\left(\mathrm{NH}_{4}\right)_{2} \mathrm{SO}_{4}, 0.1 \mathrm{KH}_{2} \mathrm{PO}_{4}, 0.05 \mathrm{MgSO}_{4}, 0.25$ Yeast extract; These chemicals were added to the filtrate from saccharified biomasses (Bagasse, rice straw, wheat straw) and sterilized at $121{ }^{\circ} \mathrm{C}$ for $15 \mathrm{~min}$. After sterilization the medium was allowed to cool at room temperature. After that one milliliter suspension of Sacchromyces cervisea were inoculated and incubated anaerobically at $30{ }^{\circ} \mathrm{C}$ for four days of fermentation period. After termination of the fermentation period, ethanol produced was estimated and the ethanol yield was calculated by using following formula as described in Yoswathana and Phuriphipat (2010).

$$
\text { Ethanol yield }=\frac{\text { Measured ethanol in sample }(\mathrm{g})}{* \text { Theoretical ethanol }(\mathrm{g})}
$$

*Theoratical ethanol = amount of initial sugar content $(\mathrm{g})$ in fermentation solution $\mathrm{x} 0.5$

\section{Estimation of ethanol}

The ethanol content was measured spectrophotometrically as described by Caputi et al. (1968). One milliliter of the fermented sample was taken in $500 \mathrm{~mL}$ Pyrex distillation flask containing $30 \mathrm{~mL}$ of distilled water. The distillate was collected in $50 \mathrm{~mL}$ flask containing $25 \mathrm{~mL}$ of potassium dichromate solution About $20 \mathrm{~mL}$ of distillate was 
collected in each sample and the flasks were kept in a water bath maintained at $60^{\circ} \mathrm{C}$ for $20 \mathrm{~min}$. The flasks were cooled to room temperature and the volume raised to $50 \mathrm{~mL}$. Five $\mathrm{mL}$ of this was diluted with $5 \mathrm{~mL}$ of distilled water for measuring the optical density at $600 \mathrm{~nm}$ using a spectrophotometer.

\section{Estimation of sugars}

Reducing sugars were estimated by the method of Miller (1959) and total sugars were measured by the method as described by Duboise et al. (1956).

\section{Fourier transform infra red spectroscopy of substrates}

FTIR was used to check the chemical changes in treated and untreated samples as described earlier (Irfan $e t$ al., 2011b). Mixture of sample and $\operatorname{KBr}(5 \%$ sample : $95 \%$ $\mathrm{KBr}$ ) were passed into a disk for Fourier Transform Infrared Spectroscopy measurement. The spectrum was recorded with 32 scans in the frequency range of 4000$400 \mathrm{~cm}^{-1}$ with a resolution of $4 \mathrm{~cm}^{-1}$.

\section{Statistical analysis}

Statistical analysis was done by ANOVA test using Microsoft Excel program. The difference in values was indicated in the form of probability $(\mathrm{p}<0.05)$ values.

\section{Results and Discussion}

In this study three different substrates like sugarcane Bagasse, rice straw and wheat straw were used for ethanol production by Sacchromyces cerisae in $500 \mathrm{~mL}$ Erlenmyer flask at $30^{\circ} \mathrm{C}$ for four days of fermentation period. For ethanol production, pretreatment of substrate is first step which disrupt the entire structure of the biomass and provides more surface area for enzymatic action. So, all these substrates i.e. sugarcane Bagasse, rice straw and wheat straw were first subjected to physical pretreatment which is size reduction and forming into powder form $(2 \mathrm{~mm})$ and then applied to chemical pretreatment $\left(3 \% \mathrm{H}_{2} \mathrm{O}_{2}+2 \%\right.$ $\mathrm{NaOH}$ ) followed by pressurized heating at $130{ }^{\circ} \mathrm{C}$ for $60 \mathrm{~min}$. In native form cellulose is present in crystalline form which affects the enzymatic hydrolysis (Kumar et al., 2009). Table 1 summarizes the lignin content in untreated and treated substrates. Lignin removal in terms of delignification was found to be $77.8 \%, 52.2 \%$ and $56.1 \%$ in sugarcane bagasse, wheat straw and rice straw showing the effects of pretreatment respectively. After that the pretreated biomass was analyzed by Fourier transform infrared spectroscopy to check the structural changes created by this pretreatment technique. FT-IR spectroscopy is a powerful tool for studying the physico-chemical and conformational properties of polysaccharides (Sun et al., 2000).

Figure 1 showed the FTIR spectroscopic analysis of wheat straw under three condition; untreated, pretreated and saccharified. The main bond between hemicellolose
Table 1 - Lignin content in treated and untreated substrates.

\begin{tabular}{lccc}
\hline Substrate & $\begin{array}{c}\text { Lignin in un- } \\
\text { treated (\%) }\end{array}$ & $\begin{array}{c}\text { Lignin in } \\
\text { treated (\%) }\end{array}$ & $\begin{array}{c}\text { Delignification } \\
(\%)\end{array}$ \\
\hline Sugarcane bagasse & 23 & 5.1 & 77.8 \\
Wheat straw & 17.3 & 8.1 & 52.2 \\
Rice straw & 13 & 5.7 & 56.1 \\
\hline
\end{tabular}

and lignin was $\mathrm{C}-\mathrm{O}-\mathrm{C}$ having a characterstic absorption peak at $1420.93 \mathrm{~cm}^{-1}$ and $1382.82 \mathrm{~cm}^{-1}$ which was shown in untreated wheat straw and these peaks were not as sharp or clear in treated wheat straw revealing the dislocation of hemicellulose and lignin components. The prominent peaks at $1021.21,1252.93$ and $1420.93 \mathrm{~cm}^{-1}$ represents the $\mathrm{CH}, \mathrm{OH}$, or $\mathrm{CH}_{2}$ bending frequencies (Himmelsbach et al., 2002) also showed the presence of hemicellulose (Mwaikambo and Ansell, 2002). Peaks in range of $3400 \mathrm{~cm}^{-1}$ represent the stretching vibration in $\mathrm{OH}$ (Xiao et al., 2001; Sun et al., 2000). Han et al. (2012) pretreated wheat straw with $\mathrm{NaOH}$ and reported that pretreatment produced a significant structural modification as evidenced by FTIR and SEM analysis.

Figure 2 shows the spectrum of treated, untreated and saccharified sugarcane bagasse. The result indicated that there is degradation of fibriller structure of cellulose and lignin to greater extent. The absorbance at 3655,2914 , $1601,1239,1034, \mathrm{~cm}^{-1}$ in Figure 2a are associated with untreated sugarcane bagasse as reported by Sun et al. (2001). The band at $3334.2 \mathrm{~cm}^{-1}$ is depicting the stretching of hydroxyl group in treated bagasse (Figure $2 b$ ). The absorption at $2920.22 \mathrm{~cm}^{-1}$ in treated sugarcane bagasse arises from C-H stretching, moreover the absorbance at 1423.70, $1381.56,1161.06$ and $1022.55 \mathrm{~cm}^{-1}$ corresponds to the aromatic skeleton vibration and ring breathing in the $\mathrm{C}-\mathrm{O}$ stretching in lignin (Sun et al., 2000). The peak at $1381.56 \mathrm{~cm}^{-1}$ is attributed to absorption by C-H and C-O stretching in acetyl group in hemicellulose respectively. The strong band at $1161.06 \mathrm{~cm}^{-1}$ in pretreated sugarcane bagasse was assigned to $\mathrm{C}-\mathrm{O}$ stretching in cellulose, hemicellulose and lignin or $\mathrm{C}-\mathrm{O}-\mathrm{C}$ stretching in cellulose and hemicelluloses. The band at $897.02 \mathrm{~cm}^{-1}$ is due to glucosidic linkage (Liu et al., 2007).

Figure 3 illustrated the IR spectroscopic analysis of untreated, pretreated and saccharified rice straw. A dominant peak at $1043.48 \mathrm{~cm}^{-1}$ corresponds to $\mathrm{C}-\mathrm{O}$ stretching in cellulose, hemicellulose and lignin, or C-O-C stretching in cellulose and hemicellulose (Williams and Nugranad, 2000) and this band was much expanded in pretreated rice straw which is showing the separation in some parts of cellulose, hemicellulose and lignin. Small peaks at 1378.90, 1422.76 and $1510.69 \mathrm{~cm}^{-1}$ communicate to the aromatic skeletal vibrations and ring breathing with $\mathrm{C}-\mathrm{O}$ stretching in lignin. A small peak at $897.32 \mathrm{~cm}^{-1}$ represents the $\alpha$-glucosilic linkages between the sugar units in cellulose and 


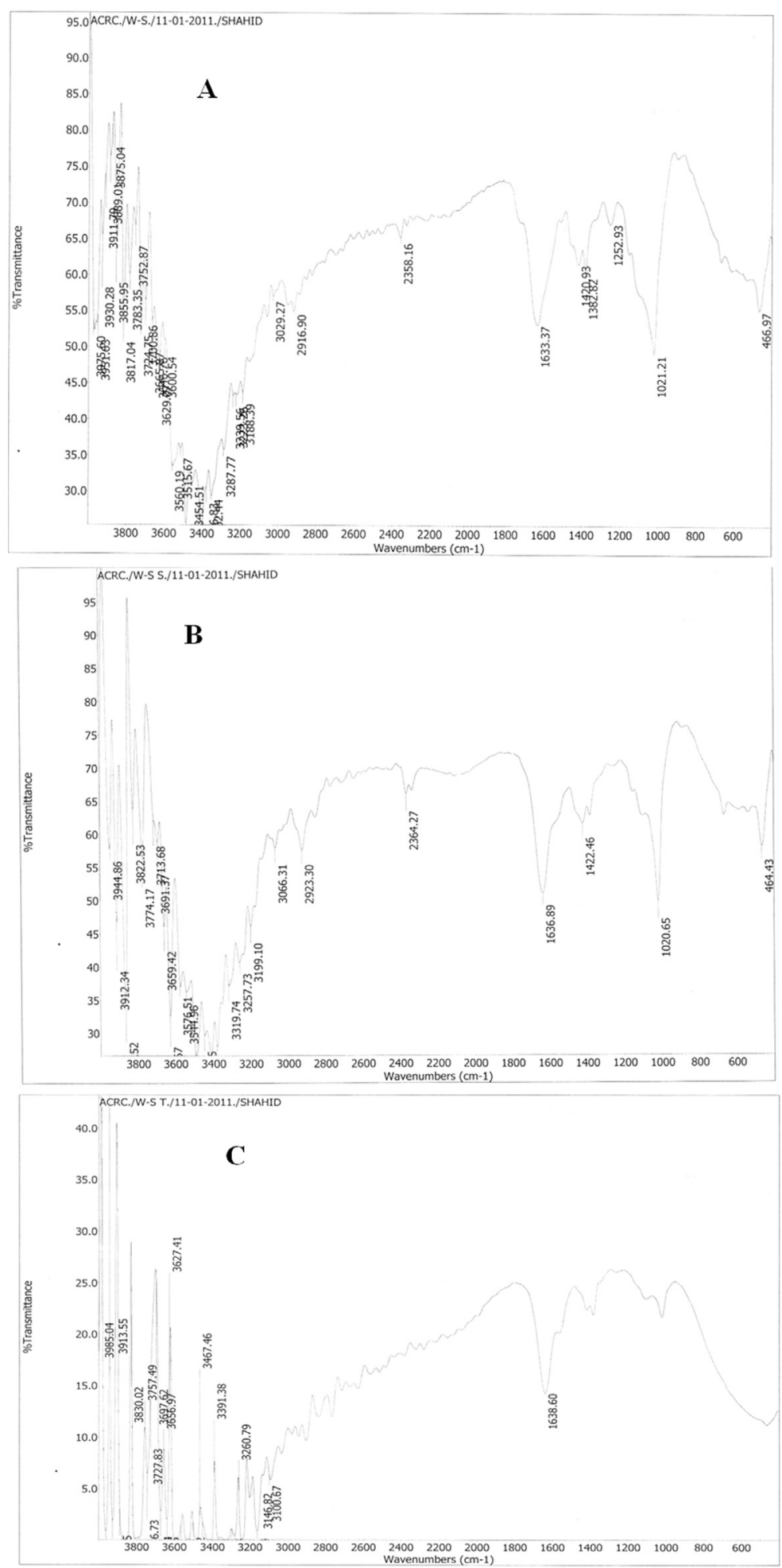

Figure 1 - FTIR spectra of (A) Untreated Wheat straw (B) Saccharified wheat straw (C) pretreated wheat straw.

hemicellulose. Sharp and large band at $1638.94 \mathrm{~cm}^{-1}$ and $2916.63 \mathrm{~cm}^{-1}$ denotes the stretching in C-O and C-H bonds. From this FTIR study of the substrates, it was observed that pretreatment had significantly alter the structures of the substrate thus loosing the cellulose, hemicelluose and lignin connections thus leading to efficient enzymatic attacks.

After pretreatment, each substrate was saccharified by using commercial enzyme at $50^{\circ} \mathrm{C}$ for $8 \mathrm{~h}$. Results (Figure 4) indicated that maximum saccharification was done 

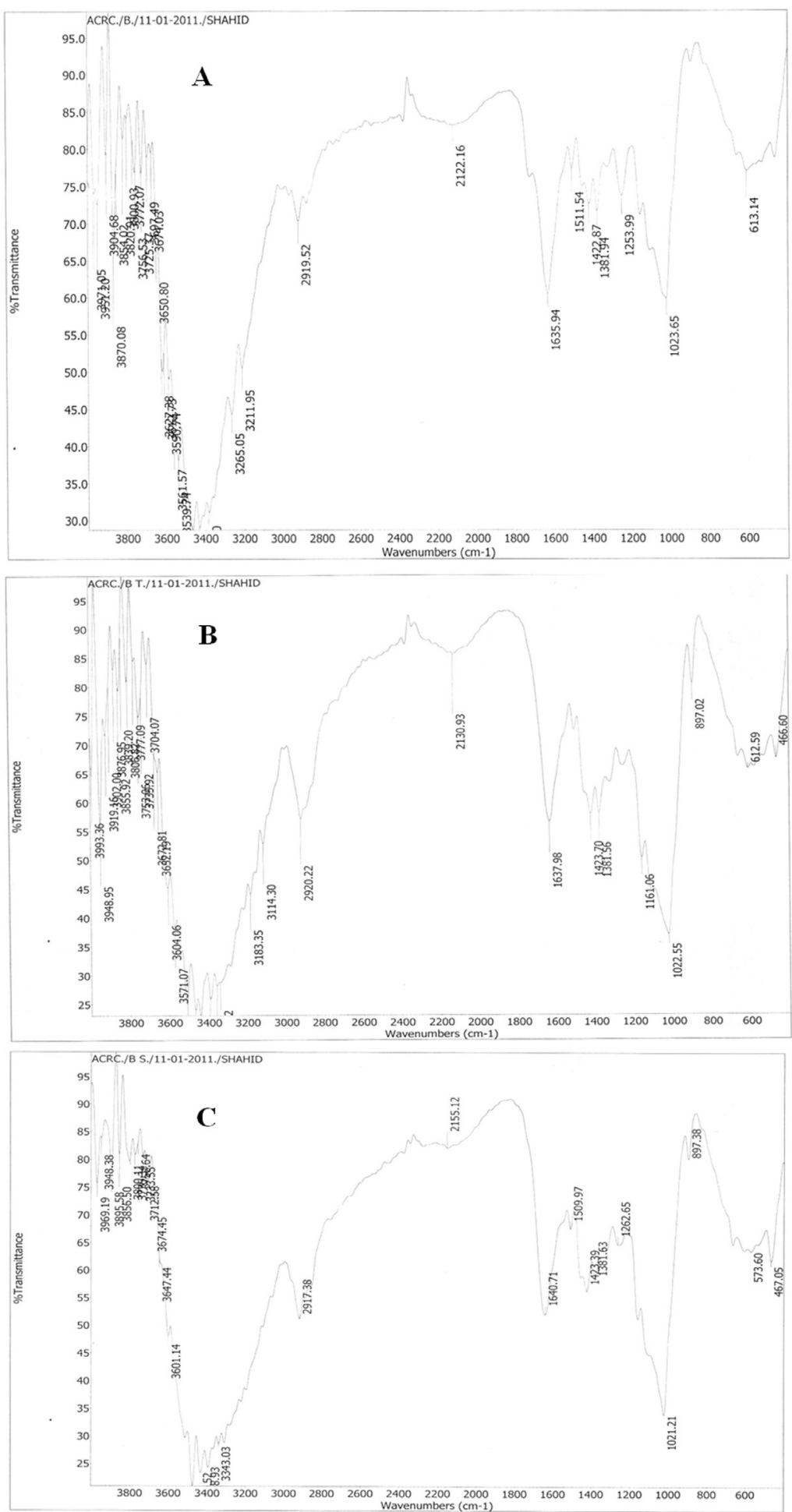

Figure 2 - FTIR spectra of (A) Untreated sugarcane Bagasse (B) pretreated sugarcane Bagasse (C) Saccharified sugarcane.

with sugarcane bagasse (64\%) followed by rice straw (40\%) and wheat straw (34\%). Maximum saccharification of sugarcane bagasse is due to the presence of more cellulose and saccharification rate also vary with the presence of cellulosic content in biomasses. In another report maximum saccharification rate of $33.0,25.5$, and $35.5 \%$ were obtained with $2 \% \mathrm{NaOH}$ pretreated wheat straw, rice straw and bagasse, respectively (Akhtar et al., 2001).

Figure 5 illustrate the ethanol production from bagasse, rice straw and wheat straw by Sacchromyces cervisiae in submerged fermentation at $30^{\circ} \mathrm{C}$ for four days of incubation. Results indicated that maximum ethanol pro- 


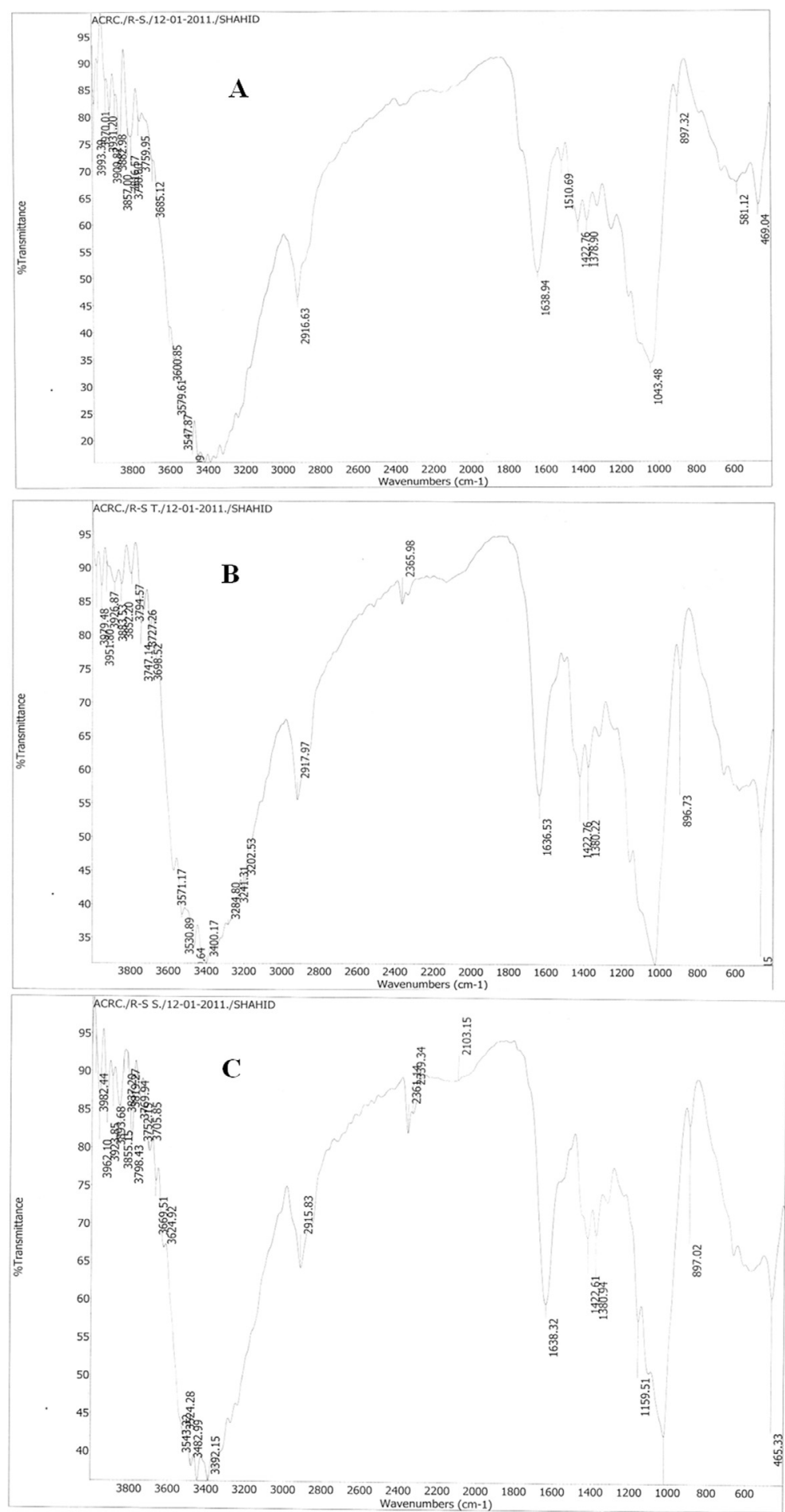

Figure 3 - FTIR spectra of (A) Untreated Rice straw (B) pretreated Rice straw (C) Saccharified Rice straw.

duction was observed by sugarcane bagasse (66 g/L) with ethanol yield of 0.41 . Rice straw $(49 \mathrm{~g} / \mathrm{L})$ and wheat straw ( $34 \mathrm{~g} / \mathrm{L})$ also produced ethanol but their production is not good as compared to sugarcane bagasse. This difference in ethanol production was due to the availability of fermentable sugars from cellulose present in biomasses. Jalil et al. (2010) used commercial enzyme for saccharification and reported that treated rice straw gave better ethanol production $(85 \mathrm{~g} / \mathrm{L})$ as compared to untreated $(70 \mathrm{~g} / \mathrm{L})$ rice straw. Uma et al. (2010) pretreated sugarcane bagasse with $1 \mathrm{~N}$ $\mathrm{NaOH}$ and obtained $48 \%$ ethanol production by $C$. cladosporoides after $48 \mathrm{~h}$ of fermentation under static condition. Sasikumar and Viruthagiri (2010) obtained maximum ethanol production $(3.36 \mathrm{~g} / \mathrm{L})$ from pretreated 


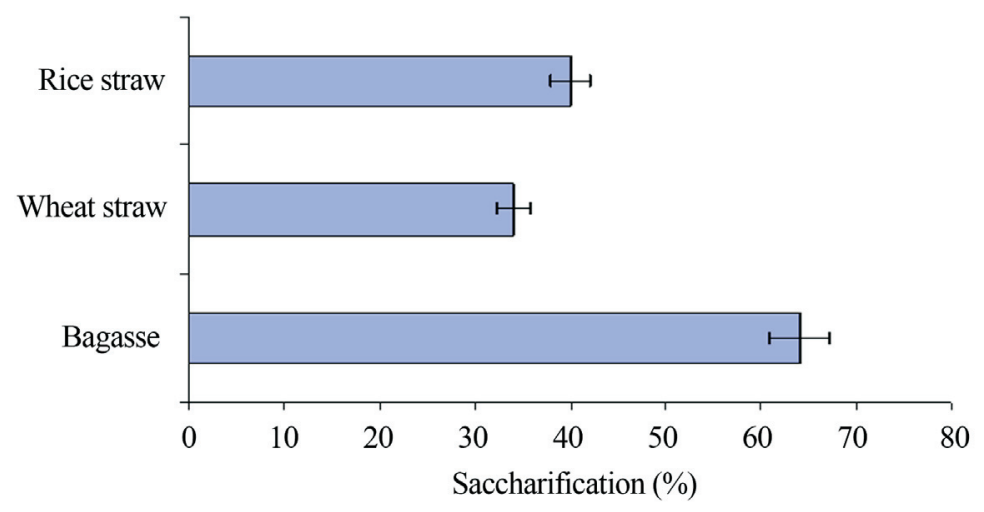

Figure 4 - Saccharification of different lignocellulosic biomasses.
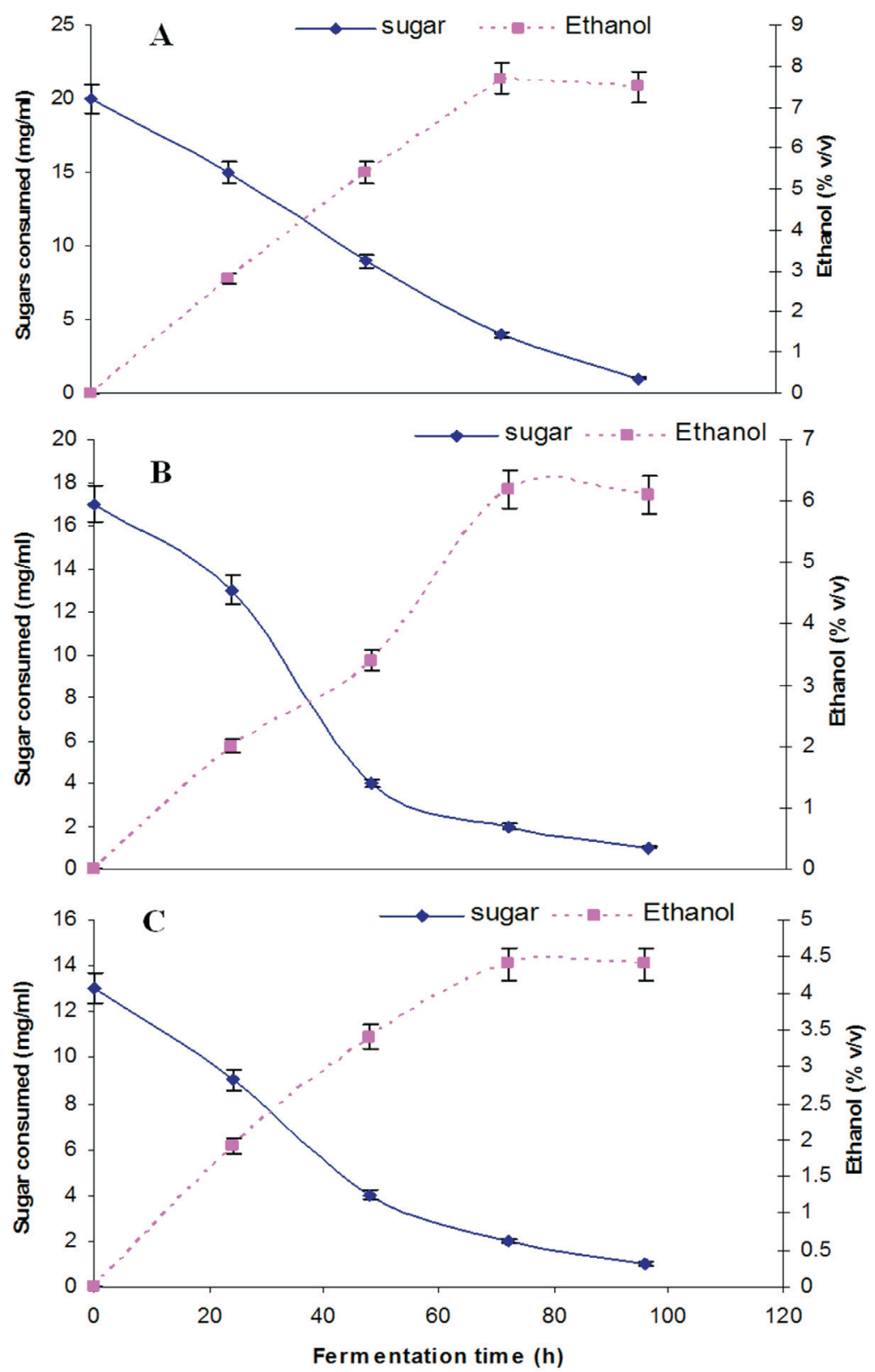

Figure 5 - Time course of ethanol production on various substrates (A) sugarcane bagasse (B) Rice straw and (C) Wheat straw. 


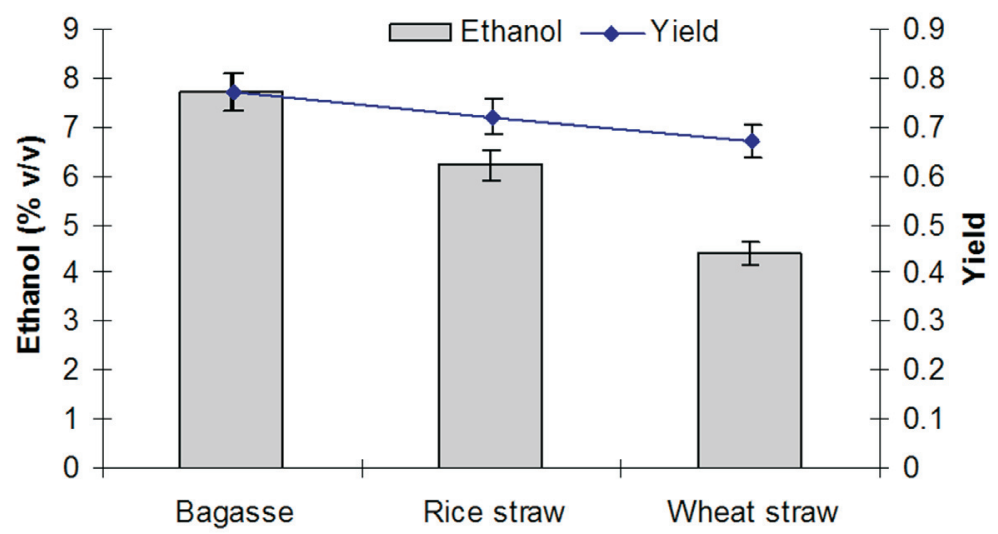

Figure 6 - Ethanol production from different lignocellulosic biomasses.

sugarcane bagasse under optimized process conditions in aerobic batch fermentation.

\section{Conclusion}

Results of this study revealed that pretreatment of the substrate are necessary for obtaining of more sugars as a result of enzymatic hydrolysis. The sugars produced by enzymatic hydrolysis were readily converted into ethanol by using S.cervisae in submerged fermentation at $30{ }^{\circ} \mathrm{C}$ for four days of incubation. Sugarcane bagasse is found to be very effective substrate for ethanol production and this might be helpful for scaling up and make the process cost effective.

\section{Acknowledgement}

This research work was financially supported by the Ministry of Science and Technology, Islamabad Pakistan under the project "Production of Bioenergy from Plant Biomass".

\section{References}

Akhtar MS, Saleem M, Akhtar MW (2001). Saccharification of Lignocellulosic Materials by the Cellulases of Bacillus subtilis. Int J Agri Biol 3:2.

Ballesteros M, Oliva JM, Negro MJ, Manzanares P, Ballesteros I (2004). Ethanol from lignocellulosic materials by a simultaneous saccharification and fermentation process SFS with Kluyveromyces marxianus CECT 10875. Proc Biochem 39:1843-1848.

Caputi A, Ueda M, Brown T (1968). Spectrophotometric determination of ethanol in wine. Am J Enol Vitic 19:160-165.

Curreli N, Agelli M, Pisu B, Rescigno A, Sanjust E, Rinaldi A (2002). Complete and efficient enzymic hydrolysis of pretreated wheat straw. Proc. Biochem 37:937-941.

Curreli N, Fadda MB, Rescigno A, Rinaldi AC, Soddu G, Sollai F (1997). Mild alkaline/oxidative pretreatment of wheat straw. Proc Biochem 32:665-670.

Duboise M, Gilles KA, Hamilton JK, Rebers PA, Smith F (1956). Calorimetric method for determination of sugars and related substances. Ana Chem 28:350-356.
Gervais P, Sarrette M (1990). Influence of age of mycelia and water activity on aroma production by Trichoderma viride. $\mathrm{J}$ Ferment Bioengin 69:46-50.

Gong CS, Maun CM, Tsao GT (1981). Direct fermentation of cellulose to ethanol by a cellulolytic filamentous fungus Monilia sp. Biotechnol Lett 3:77-82

Gruno M, Vaeljamaee P, Pettersson G, Johansson G (2004). Inhibition of the Trichoderma reesei cellulases by cellobiose is strongly dependent on the nature of the substrate. Biotechnol Bioengin 86:503-511.

Han L, Feng J, Zhang S, Ma Z, Wang Y, Zhang X (2012). Alkali pretreatment of wheat straw and its enzymatic hydrolysis. Braz J Microb 43:53-61.

Himmelsbach DS, Khalili S, Akin DE (2002). The use of FT-IR microspectroscopic mapping to study the effects of enzymatic retting of flax Linum usitatissium L.. stems. J Sci Food Agri 82:685-696.

Ingram LO, Conway T, Clark DP, Sewell GW, Preston JF (1987). Genetic engineering of ethanol production in Escherichia coli. Appl Environ Microbiol 53:2420-2425.

Irfan M, Gulsher M, Abbas S, Syed Q, Nadeem M, Baig S (2011a). Effect of various pretreatment conditions on enzymatic saccharification. Songklanakarin J Sci Technol 33:397-404.

Irfan M, Syed Q, Abbas S, GulSher M, Baig S, Nadeem M (2011b). FTIR and SEM analysis of thermo-chemical fractionated of Sugarcane Bagasse. Turk J Biochem 36:322-328.

Ito K, Yoshida K, Ishikawa T, Kobayashi S (1990). Volatile compounds produced by fungus Aspergillus oryzae in rice koji and their changes during cultivation. J Ferment Bioengin 70:169-172.

Jalil R, Ibrahim WA, Ali MSM, Hashim S, Elham P, Tahar A, Zahidi NFA (2010). $7^{\text {th }}$ Biomass Asia Workshop, November 29-December 01, Jakarta, Indonesia.

Kim S, Dale BE (2004). Global potential bioethanol production from wasted crops and crop residues. Biomass Bioeng 26:361-375.

Kim TH, Lee YY (2007). Pretreatment of corn stover by soaking in aqueous ammonia at moderate temperatures. Appl Biochem Biotechnol 136-140:81-92.

Krishna HS, Chowdary GV, Reddy SD, Ayyanna C (1999). Simultaneous saccharification and fermentation of pretreated Antigonum leptopus Linn. leaves to ethanol. J Chem Technol Biotechnol 74:1055-1060. 
Kumar R, Chandrashekar N, Pandey KK (2009). Fuel properties and combustion characteristics Lantana camara and Eupatorium spp. Curr Sci 97:930-934.

Liu CF, Sun RC, Qin MH, Zhang AP, Ren JL, Xu F, Ye J, Wu SB (2007). Chemical modification of ultrasound pretreated sugarcane bagasse with maleic anhydride. Ind Crop Prod 26:212-219.

MacDonald T, Yowell G, McCormack M (2001). Staff report. US ethanol industry production capacity outlook. California energy commission. Available at http//www.energy.ca.gov/reports/2001-08-29_600-01-017.PDF.

Matthew H, Ashley O, Brian K, Alisa E, Benjamin JS (2005). Wine making 101.Available at http//www.arches.uga.edu/ matthaas/strains.htm.

Miller GL (1959). Use of dinitrosalicylic acid reagent for determination of reducing sugars. Ana Chem 31:426-428.

Millichip RJ, Doelle HW (1989). Large-scale ethanol production from Milo Sorghum using Zymomonas mobilis. Proc Biochem 24:141-145.

Mosier N, Wyman C, Dale B, Elander R, Lee YY, Holtzapple M, Ladisch M (2005). Features of promising technologies for pretreatment of lignocellulosic biomass. Biores Technol 96:673-686.

Mwaikambo LY, Ansell MP (2002). Chemical modification of hemp sisal jute and kapok fibers by alkalization. J Appl Polym Sci 84:2222-2234.

Pastore GM, Park YK, Min DB (1994). Production of a fruity aroma by Neurospora from beiju. Mycol Res 98:25-35.

Saddler JN, Chan MKH (1982). Optimization of Clostridium thermocellum growth on cellulose and pretreated wood substrates. European J Appl Microbiol Biotechnol 16:99-104.

Sasikumar E, Viruthagiri T (2010). Simultaneous Saccharification and Fermentation SSF of Sugarcane Bagasse - Kinetics and Modeling. Int J Chem Biol Engin 32.
Sugawara E, Hashimoto S, Sakurai Y, Kobayashi A (1994). Formation by yeast of the HEMF 4-hydrpxy-2 or 5.-ethyl-5 or 2.-methyl-3 2H.-furanone. aroma components in Miso with aging. Biosci Biotechnol Biochem 58:1134-1135.

Sun JX, Sun XF, Sun RC, Fowler P, Baird MS (2003). Inhomogenties in the chemical structure of sugarcane bagasse lignin. J Agri Food chem 51:6719-6725.

Sun RC, Tomkinson J, Mao FC (2001). Physiochemical characterization of lignins from rice straw by hydrogen peroxide treatment. J Appl Polym Sci 79:719-732.

Sun RC, Tomkinson J, Wang YW, Xiao B (2000). Physicochemical and structural characterization of hemicelluloses from wheat straw by alkaline peroxide extraction. Polymer 41:2647-2656.

Uma C, Muthulakshmi C, Gomathi D, Gopalakrishnan VK (2010). Fungal invertase as aid for production of ethanol from sugarcane bagasse. Res J Microbiol 5:980-985.

Williams PT, Nugranad N (2000). Comparison of products from the pyrolysis and catalytic pyrolysis of rice husks. Energy 25:493-513.

Xiao B, Sun XF, Sun RC (2001). Chemical, structural and thermal characterization of alkali soluble lignins and hemicelluloses and cellulose from maize stems, rye straw and rice straw. Polym Degrad Stab 74:307-319.

Yamauchi H, Akita O, Obata T, Amachi T, Hara S (1989). Production and application of a fruity odor in a solid state culture of Neurospora sp. using pregelatinized polish rice. Agric Biol Chem 53:2881-2888.

Yoswathana N, Phuriphipat P (2010). Bioethanol Production from Rice Straw. Energy Res J 11:26-31.

All the content of the journal, except where otherwise noted, is licensed under a Creative Commons License CC BY-NC. 